\title{
Proceeding
}

Supplementary Issue: Spring Conferences of Sports Science. 15th Convention and Workshop of the International Network of Sport and Health Science, 5-8 June 2019. University of Las Palmas de Gran Canaria, Las Palmas de Gran Canaria, Spain.

\section{Normal people's capacity of adjustment on a wheelchair basket: A preliminary study}

\author{
STEFANIA BOCCIA ${ }^{1}$, MANUELA VALENTINI², ARIO FEDERICI ${ }^{2}$, GAETANO ALTAVILLA ${ }^{3}$ \\ 1 University of Salerno, Italy \\ 2University Carlo Bo of Urbino, Italy \\ ${ }^{3}$ Faculty of Kinesiology, University of Split, Croatia
}

\begin{abstract}
The purpose of this work is to show the execution and the results of a study aimed at identifying and defining the level of the normal people's capacity of adjustment on a wheelchair. This study is based on an hypothesis of a readaptation of a sport's rules of basketball. The new regulation created supposes the contemporary participation of normal people and disabled people and it establishes the use of wheelchairs regardless the physical condition and performance. All of this has been decided to minimize possible physical differences. Consequently, the study was conducted on some young basketball athletes to achieve the intended goal. The chosen athletes are member of an under 15 regional championship. The test administered to them includes some time and precision exercises based on the main fundamentals of basketball, executed on a wheelchair. The test's administration took place in three days to judge the speed of adaptation and learning of using this new tool. The sample group seemed available and open to this first approach with a mobile device used mainly by disabled people, but the results of the study done weren't positive. So, the $30 \%$ of the group has provided excellent results and it has been able to perform the test discreetly, improving each time. On the other hand, the remaining $70 \%$ observed many problems, worsening their performance in the last drills. Keywords: Disabled athletes; Physical adapted activity; Testing.
\end{abstract}

\section{Cite this article as:}

Boccia, S., Valentini, M., Federici, A., \& Altavilla, G. (2019). Normal people's capacity of adjustment on a wheelchair basket: A preliminary study. Journal of Human Sport and Exercise, 14(4proc), S646-S653. doi:https://doi.org/10.14198/ihse.2019.14.Proc4.24

Corresponding author. Faculty of Kinesiology, University of Split, Croatia.

E-mail: gaetano.altavilla @libero.it

Supplementary Issue: Spring Conferences of Sports Science. 15th Convention and Workshop of the International Network of Sport and Health Science, 5-8 June 2019. University of Las Palmas de Gran Canaria, Las Palmas de Gran Canaria, Spain. JOURNAL OF HUMAN SPORT \& EXERCISE ISSN 1988-5202

(c) Faculty of Education. University of Alicante doi:10.14198/jhse.2019.14.Proc4.24 


\section{INTRODUCTION}

The study considered is based on the hypothesis of a readaptation of basketball's rules (Martino et al., 2019), to allow normal people and disabled people to play at the same time. To do this, a new technological instrument has been planned: a wheelchair characterised by the presence of special sensors, which favour the translocation in space simply through the displacement of the centre of gravity of the athlete, favouring every single disability (Di Tore et al., 2012) and so to improve the health status (Tiziana et al, 2017, Gaetano, 2016). The assessment is the main issue to evaluate (D'lsanto et al., 2019, Altavilla et al, 2018b, Raiola, D'Isanto, 2017b), including technical skills (Altavilla et al, 2018a, Raiola, D'Isanto, 2017b, Raiola, 2015) because is the basis of scientific identity of exercise and sports sciences training (D'elia, 2019, Sanseviero et al, 2019, Ceciliani, 2018, D'Elia et al, 2018, Raiola et al., 2018, Raiola, 2017, Raiola, Di Tore, 2017, Ceciliani et al, 2005).

As a result, the proposed study aims to observe and evaluate the adaptability of young athletes with a wheelchair, a characterizing element of the regulation taken into account. (Fay et al., 2013).

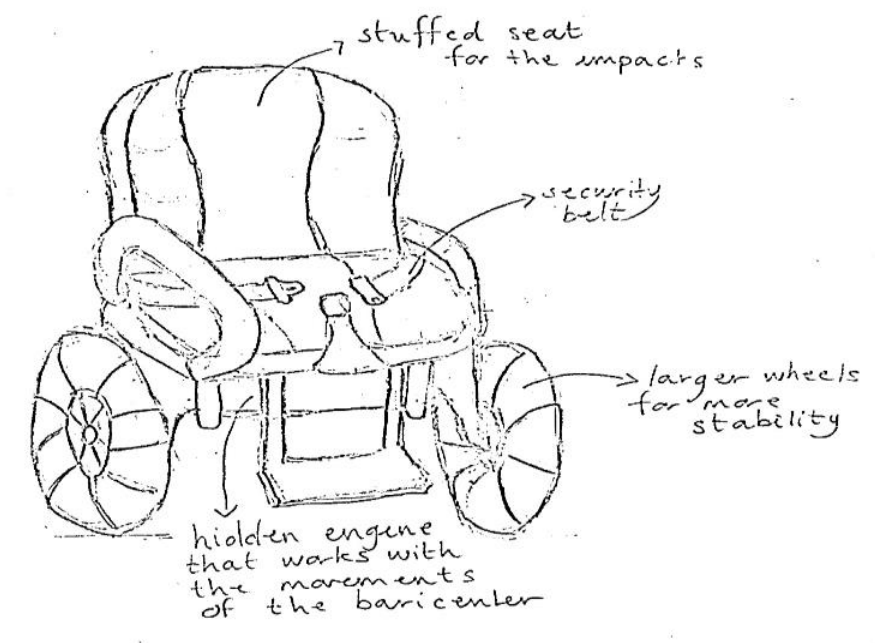

Figure 1. Wheelchair prototype with hoverboard sensors.

\section{METHODS}

\section{Sample of subjects}

This work was carried out mainly on a heterogeneous sample of 10 young athletes $\mathrm{U} 15$ entered in a regional championship, through the use of a basketball court, a basket and a ball with regulations and above all, of a wheelchair.

\section{Procedures}

The data were taken in two different periods on four weeks (at the start of the first week and after one month), in order to verify an improvement or a worsening of the performance on the wheelchair. These data are related to the execution of some exercises on the main fundamentals of basketball: shooting, dribbling and passing. All players were informed of all the procedures and they have voluntarily participated in this research. 


\section{Statistical analysis}

The analysis covered basic statistics and percentages for the categories considered. The normality of data distribution was verified with Kolmogorov-Smirnov test. T-test was used to show the significant differences between before and post training. The significance level was set at $p<0.05$. Statistical analyses were carried out with the software «IBM SPSS23». (Di Tore et al., 2013).

\section{RESULTS}

As far as shooting is concerned, the proposed exercise is to carry out the basic of shooting from five different locations within the three point line, giving each athlete five attempts for each of them (25 total throws). The positions (Fig. 2) planned were: angles, free throw extensions and free throw.(Schwark et al., 2004).

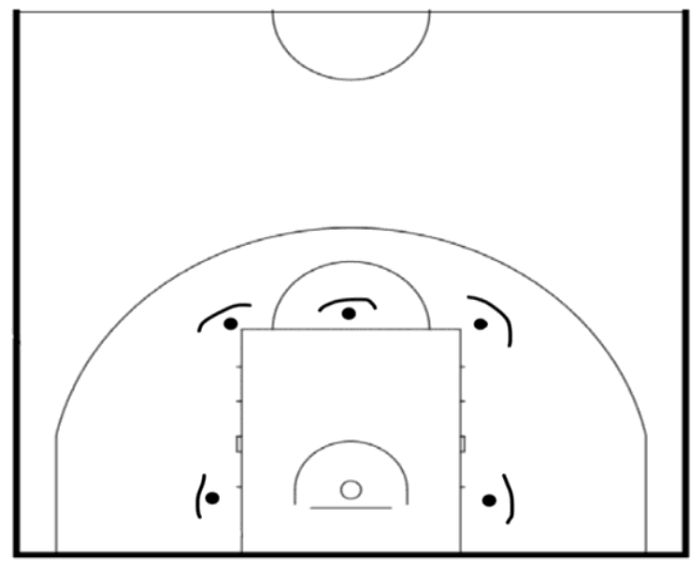

Figure 2. Positions of shooting.

Despite being well prepared on the fundamental considered, the athletes have found a few difficulties in the execution to be seated. In table 1, the data taken have shown the complexity of the test. Only some athletes were able to improve from the standpoint of realization, the others have continued to experience the same difficulties "Initial". The table below show the throws made on the 25 attempts available.

Table 1. Results of the shooting test

\begin{tabular}{lcc}
\hline SHOOTING & Initial & Final (after one month) \\
\hline Athlete 1 & $8 / 25$ & $10 / 25$ \\
Athlete 2 & $2 / 25$ & $2 / 25$ \\
Athlete 3 & $4 / 25$ & $3 / 25$ \\
Athlete 4 & $5 / 25$ & $3 / 25$ \\
Athlete 5 & $0 / 25$ & $5 / 25$ \\
Athlete 6 & $1 / 25$ & $0 / 25$ \\
Athlete 7 & $6 / 25$ & $2 / 25$ \\
Athlete 8 & $2 / 25$ & $7 / 25$ \\
Athlete 9 & $1 / 25$ & $0 / 25$ \\
Athlete 10 & $3 / 25$ & $1 / 25$ \\
\hline Total & $\mathbf{3 2 / 2 5 0}$ & $\mathbf{3 3 / 2 5 0}$ \\
\hline
\end{tabular}


Table 2. Difference throws made between pre (initial) and post (final)

\begin{tabular}{|c|c|c|c|c|c|c|c|c|}
\hline & \multicolumn{5}{|c|}{ T-test } & \multirow{3}{*}{$t$} & \multirow{3}{*}{ gl } & \multirow{3}{*}{ Sign. (with two tails) } \\
\hline & \multirow{2}{*}{ Average } & \multirow{2}{*}{$\begin{array}{l}\text { Dev. } \\
\text { std. }\end{array}$} & \multirow{2}{*}{$\begin{array}{c}\text { Average } \\
\text { standard error }\end{array}$} & \multicolumn{2}{|c|}{$\begin{array}{l}\text { Confidence interval of } \\
\text { the difference of } 95 \%\end{array}$} & & & \\
\hline & & & & Lower & Higher & & & \\
\hline $\begin{array}{l}\text { VAR01 } \\
\text { VAR02 }\end{array}$ & -.10000 & 2.99815 & 94810 & -2.24475 & 2.04475 & -.105 & 9 & .918 \\
\hline
\end{tabular}

The significance level was set at $p<0.05$.

Instead, as regards the fundamental of the dribble, they were given a test based on the time. It involves a work on a half-field, in which the athlete makes a zigzag path around the Kinsians (shown in yellow in the drawing), dribbling once every two pushes of the wheelchair. Then, once he has reached the middle of the field, he makes a change of direction and pushes quickly to conclude to the basket. (Altavilla, Raiola, 2015).

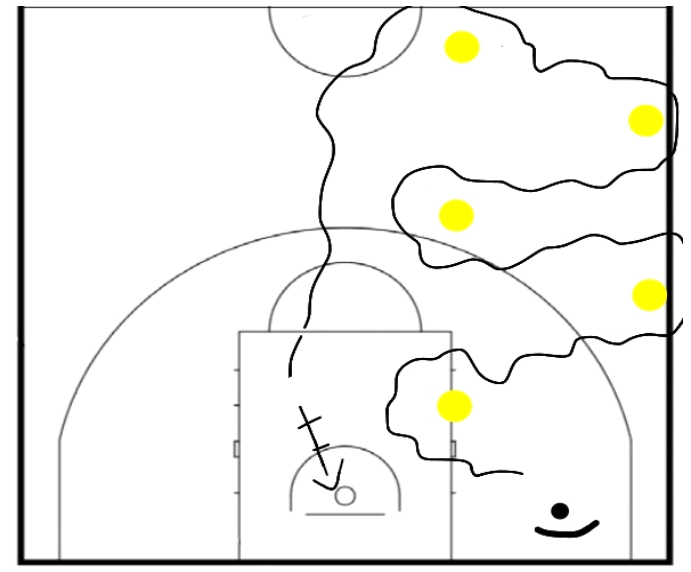

Figure 3. Time path in dribble.

The difficulty found in this test was having to push and direct the wheelchair as quickly as possible while being able to dribble. Even in this second exercise, only a small part of the sample was able to optimize the use of the wheelchair.

The results shown in table 3 are expressed in minutes and seconds.

Table 3. Results of the dribbling test

\begin{tabular}{lcc}
\hline Dribbling & Initial & Final (after one month) \\
\hline Athlete 1 & $1^{\prime} 49^{\prime \prime}$ & $1^{\prime} 45^{\prime \prime}$ \\
Athlete 2 & $1^{\prime} 55^{\prime \prime}$ & $1^{\prime} 56^{\prime \prime}$ \\
Athlete 3 & $1^{\prime} 59^{\prime \prime}$ & $2^{\prime} 06^{\prime \prime}$ \\
Athlete 4 & $2^{\prime} 00^{\prime \prime}$ & $2^{\prime} 10^{\prime \prime}$ \\
Athlete 5 & $1^{\prime} 44^{\prime \prime}$ & $1^{\prime} 41^{\prime \prime}$ \\
Athlete 6 & $2^{\prime} 04^{\prime \prime}$ & $2^{\prime} 12^{\prime \prime}$ \\
Athlete 7 & $1^{\prime} 53^{\prime \prime}$ & $1^{\prime} 56^{\prime \prime}$ \\
Athlete 8 & $1^{\prime} 39^{\prime \prime}$ & $1^{\prime} 33^{\prime \prime}$ \\
Athlete 9 & $1^{\prime} 37^{\prime \prime}$ & $1^{\prime} 41^{\prime \prime}$ \\
Athlete 10 & $1{ }^{\prime \prime} 38^{\prime \prime}$ & $1^{\prime} 45^{\prime \prime}$ \\
\hline
\end{tabular}


Table 4. Difference dribbling between pre (initial) and post (final)

\begin{tabular}{|c|c|c|c|c|c|c|c|c|}
\hline & \multicolumn{5}{|c|}{ T-test } & \multirow{3}{*}{$\mathrm{t}$} & \multirow{3}{*}{ gl } & \multirow{3}{*}{$\begin{array}{l}\text { Sign. (with } \\
\text { two tails) }\end{array}$} \\
\hline & \multirow[t]{2}{*}{ Average } & \multirow[t]{2}{*}{ Dev. std. } & \multirow{2}{*}{$\begin{array}{c}\text { Average } \\
\text { standard } \\
\text { error }\end{array}$} & \multicolumn{2}{|c|}{$\begin{array}{c}\text { Confidence interval of the } \\
\text { difference of } 95 \%\end{array}$} & & & \\
\hline & & & & Lower & Higher & & & \\
\hline $\begin{array}{l}\text { VAR01 } \\
\text { VAR02 }\end{array}$ & -.06700 & .15129 & .04784 & -.17523 & .04123 & -1.400 & 9 & .195 \\
\hline
\end{tabular}

The significance level was set at $p<0.05$.

Then, the last proposed test was related to another fundamental of basketball, the passing.

The type of passing taken into account is the two-handed chest pass. The exercise predicts that the player with the wheelchair and the ball is in the guard position, while the other athlete in low post.

The first one will have to carry out exactly three passes to the chest to the companion that will move in three different positions: low post and in forward. (Oudejans et al., 2012).

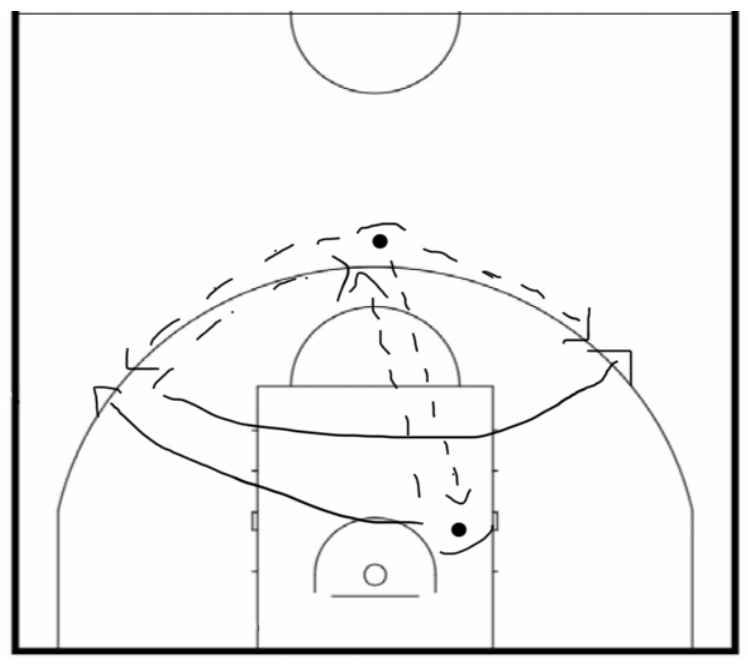

Figure 4. Dotted line: passing; continuous line: movement without ball

The results obtained from this last test were rather similar to the previous ones.

Most of the sample showed significant problems in dosing the force in the two-handed chest pass. In fact, the fundamental done from the majority of the athletes was particularly short.

In some cases, the ball did not reach at all the second player involved in the test, or at most, the passage was so weak that it dropped only at the feet of the companion. Some athletes tended to lean their feet on the ground to be able to give a greater thrust to the ball, cancelling the attempt to pass. As can be seen from Table 5., which shows the number of successful passes per player, only a fraction of the sample has been able to improve and understand the right technique to make a discreet transition. 
Table 5. Results of the passing test

\begin{tabular}{lcc}
\hline Passing & Initial & Final (after one month) \\
\hline Athlete 1 & $2 / 3$ & $3 / 3$ \\
Athlete 2 & $1 / 3$ & $1 / 3$ \\
Athlete 3 & $0 / 3$ & $0 / 3$ \\
Athlete 4 & $2 / 3$ & $1 / 3$ \\
Athlete 5 & $3 / 3$ & $3 / 3$ \\
Athlete 6 & $3 / 3$ & $1 / 3$ \\
Athlete 7 & $2 / 3$ & $1 / 3$ \\
Athlete 8 & $1 / 3$ & $3 / 3$ \\
Athlete 9 & $1 / 3$ & $1 / 3$ \\
Athlete 10 & $2 / 3$ & $1 / 3$ \\
\hline Total & $16 / 30$ & $15 / 30$ \\
\hline
\end{tabular}

Table 6. Difference passing between pre (initial) and post (final)

\begin{tabular}{|c|c|c|c|c|c|c|c|c|}
\hline & \multicolumn{5}{|c|}{ T-test } & \multirow{3}{*}{$t$} & \multirow{3}{*}{ gl } & \multirow{3}{*}{$\begin{array}{l}\text { Sign. (with } \\
\text { two tails) }\end{array}$} \\
\hline & \multirow[t]{2}{*}{ Average } & \multirow[t]{2}{*}{ Dev. std. } & \multirow{2}{*}{$\begin{array}{c}\text { Average } \\
\text { standard error }\end{array}$} & \multicolumn{2}{|c|}{$\begin{array}{l}\text { Confidence interval of } \\
\text { the difference of } 95 \%\end{array}$} & & & \\
\hline & & & & Lower & Higher & & & \\
\hline $\begin{array}{l}\text { VAR01 } \\
\text { VAR02 }\end{array}$ & .20000 & 1.13529 & .35901 & -.61214 & 1.01214 & .557 & 9 & .591 \\
\hline
\end{tabular}

The significance level was set at $p<0.05$

\section{CONCLUSIONS}

The outcome of the study it has been enough negative, that is confirmed from the three T-test realized and shown in the tables 2,4 and 6 . Only the $30 \%$ of the sample studied was able to approach positively to a tool that it never used, such as the wheelchair. However, it is important to highlight that athletes who have achieved positive results have been the same in the three trials proposed. The players who, in fact, make up the $30 \%$ above are those who physically and technically turn out to be higher than the rest of the group of athletes.

Therefore, at the end of this study, it has come to the conclusion that the adaptability of young able-bodied athletes is particularly limited, if the attention is not focused on a work exclusively carried out on a wheelchair but regarding all instruments for disabled athlete. (Cassese, Raiola, 2017, Traballesi et al., 2009).

\section{REFERENCES}

Altavilla, G., D'Isanto, T., Di Tore, A.P., Raiola, G. (2018a) Free throw and outcomes: Pilot study on intensive training versus extensive one, Journal of Human Sport and Exercise, 13 (3), pp. 494-503. https://doi.org/10.14198/ihse.2018.133.02

Altavilla, G., Mazzeo, F., D’Elia, F., Raiola, G. (2018b) Physical commitment and specific work for each role in an elite soccer team, Journal of Physical Education and Sport, 18 (2), art. no. 83, pp. 570 574.

Altavilla, G., Raiola, G. (2015) Sports game tactic in basketball [Sport Science, 8 (1), pp. 43-46. 
Cassese, F.P., Raiola, G. (2017) The importance of sport in disability management, Sport Science, 10, pp. 7-11.

Ceciliani, A. (2018) From the embodied cognition to the embodied education in the physical and sports sciences, Encyclopaideia, 22 (51), pp. 11-24.

Ceciliani, A., Di Carlo, M., Tentoni, C. (2005) Mental process learning Medicina dello Sport, 58 (1), pp. 43-52.

D'Elia, F. (2019). The training of physical education teacher in primary school. Journal of Human Sport and Exercise, 14(1 proc), S100-S104. https://doi.org/10.14198/jhse.2019.14.Proc1.12

D'Elia, F., Mazzeo, F., Raiola, G. (2018) The core curriculum in the university training of the teacher of physical education in Italy, Journal of Human Sport and Exercise, 13, pp. S413-S420. https://doi.org/10.14198/ihse.2018.13.proc2.25

Di Tore, P.A., Discepolo, T., Di Tore, S. (2013) Natural user interfaces as a powerful tool for courseware design in physical education, Journal of E-Learning and Knowledge Society, 9 (2), pp. 109-118.

Di Tore, S., D'Elia, F., Aiello, P., Carlomagno, N., Sibilio, M. (2012) Didactics, movement and technology: New frontiers of the human-machine interaction(2012) Journal of Human Sport and Exercise, 7 (1 Special Issue), pp. S178-S184. https://doi.org/10.4100/ihse.2012.7.proc1.20

D'Isanto, T., D'Elia, F., Raiola, G., Altavilla, G. (2019) Assessment of sport performance: Theoretical aspects and practical indications, Sport Mont, 17 (1), pp. 79-82.

Fay, K., Breslin, G., Czyz, S.H., Pizlo, Z. (2013) An especial skill in elite wheelchair basketball players Human Movement Science, 32 (4), pp. 708-718. https://doi.org/10.1016/i.humov.2012.08.005

Gaetano, A. (2016) Relationship between physical inactivity and effects on individual health status, Journal of Physical Education and Sport, 16, pp. 1069-1074.

Martino, L., Fonzo, E., Cassese, F.P., D'isanto, T. (2019) Principles of adaptation of the rules for disabled athletes for an inclusion sport, Journal of Human Sport and Exercise, 14 (Proc2), pp. S215-S220. https://doi.org/10.14198/ihse.2019.14.proc2.08

Oudejans, R.R.D., Janssen, T.W.J., Heubers, S., Ruitenbeek, J.-R.J.A.C., Ruitenbeek, J.-R.J.A.C. (2012) Training visual control in wheelchair basketball shooting Research Quarterly for Exercise and Sport, 83 (3), pp. 464-469. https://doi.org/10.1080/02701367.2012.10599881

Raiola, G., D'elia, F., Altavilla, G. (2018) Physical activity and sports sciences between European Research Council and academic disciplines in Italy, Journal of Human Sport and Exercise, 13, pp. S283-S295. https://doi.org/10.14198/hse.2018.13.proc2.13

Raiola, G. (2017) Motor learning and teaching method, Journal of Physical Education and Sport, 17, art. no. 236, pp. 2239-2243.

Raiola, G., Di Tore, P.A. (2017) Motor learning in sports science: Different theoretical frameworks for different teaching methods, Sport Science, 10, pp. 50-56.

Raiola, G., D'isanto, T. (2016a) Descriptive shot analysis in basketball, Journal of Human Sport and Exercise, 11 (Proc1), pp. S259-S266. https://doi.org/10.14198//hse.2016.11.proc1.18

Raiola, G., D'isanto, T. (2016b) Assessment of periodization training in soccer, Journal of Human Sport and Exercise, 11 (Proc1), pp. S267-S278. https://doi.org/10.14198/ihse.2016.11.proc1.19

Raiola, G. (2015) Basketball feint and non-verbal communication: Empirical framework, Journal of Human Sport and Exercise, 10 (Specialissue1), pp. 360-368. https://doi.org/10.14198/ihse.2015.10.proc1.26

Sanseviero, I., Cassese, F.P., Fonzo, E., Altavilla, G., D'elia, F. (2019) Study on the master's degree in sciences of sports evaluation and sport for disabled at the University of Salerno, Italy. Journal of Human Sport and Exercise, 14 (Proc2), pp. S239-S244. https://doi.org/10.14198/ihse.2019.14.proc2.12 
Schwark, B.N., Mackenzie, S.J., Sprigings, E.J. Optimizing the release conditions for a free throw in wheelchair basketball (2004) Journal of Applied Biomechanics, 20 (2), pp. 153-166. https://doi.org/10.1123/jab.20.2.153

Tiziana, D., Antonetta, M., Gaetano, A. (2017) Health and physical activity, Sport Science, 10 (1), pp. 100-105.

Traballesi, M., Averna, T., Delussu, A.S., Polidori, L., Di Giusto, C., Di Dicarlo, C., Brunelli, S. (2009) Improvement in metabolic parameters and specific skills in an elite wheelchair basketball team: $A$ pilot study. Medicina dello Sport, 62 (1), pp. 1-16. 